\title{
HOMÍLIA MONS. VILIAMA JUDÁKA PREDNESENÁ NA PÚTI PRI PRÍLEŽITOSTI SLÁVNOSTI SV. CYRILA A METODA DŇA 5. JÚLA 2020 V NITRE A JEJ PRÍNOS K ROZVOJU CYRILO-METODSKEJ TRADÍCIE
}

\author{
Homily of Monsignor Viliam Judák for Sts. Cyril and Methodius Pilgrimage \\ Spoken on 5 July 2020 in Nitra and Its Contribution to the Development \\ of Cyrillo-Methodian Tradition
}

\author{
L’ubomír Hlad
}

DOI: 10.17846/CL.2021.14.2.176-190

\begin{abstract}
Abstrakt: HLAD, Lubomír. Homily of Monsignor Viliam Judák for Sts. Cyril and Methodius Pilgrimage Spoken on 5 July 2020 in Nitra and Its Contribution to the Development of CyrilloMethodian Tradition. The aim of the study is to analyse the text of the homily spoken by the bishop of Nitra, Monsignor Viliam Judák, at Sts. Cyril and Methodius pilgrimage on 5 July 2020 in Nitra, and to identify the elements which directly follow the line of CyrilloMethodian preaching tradition in its form and content. The preaching tradition of the saints is based on two aspects: the act of preaching per se (traditio activa) and the content of preaching (traditio passiva). The detailed exploration of the bishop's homily is grounded in the clearly defined "Cyrillo-Methodian" criteria which preaching should have according to the contemporary documents of the Magisterium. The first part of the study presents the analysis of the relevant part of Pope Francis' exhortation Evangelii gaudium (2013) which relates to the homily, as well as the analysis of the written work by Sts. Cyril and Methodius which can be considered both in the narrow and wider sense as the Cyrillo-Methodian legacy of preaching. The analysis shows that most criteria used in contemporary preaching of new evangelization are present in the work of the Slavic missionaries especially as structural features: relatedness to liturgy, comprehensibility and clarity, expressiveness, rootedness in the culture of recipients and in Biblical culture, kerygmatic trinitarianism and focus on salvation in Christ. In the second part of the study, the application of the specified criteria on the homily of Monsignor Judák from 5 July 2020 confirms that the homily is in terms of its formal features characterized by Cyrillo-Methodian comprehensibility, and in the features of the content it is characterized by Cyrillo-Methodian advocacy of moral principles, and above all by existential rootedness of Christians in the New Testament, especially in its moral doctrine which promotes an active and responsible attitude of believers and supports the common good of the nation, in its temporal as well as in the eternal dimension.
\end{abstract}

Keywords: tradition, Cyrillo-Methodian, homily, form, content, Magisterium, word, images, native culture, listening, moral principles 


\section{Úvod}

Výskum cyrilo-metodskej tradície sa v závislosti od prístupov, ktoré sú vlastné jednotlivým vedným disciplínam, vo všeobecnosti zameriava na jej dejinne uchopitelné a zmapovatelné prejavy, ako sú jazyk, cirkevno-liturgické pamiatky, architektúra, umenie či ludová zbožnosṫ. Ide o rôznorodé vyjadrenia národného dedičstva prítomného v kolektívnom povedomí, ktorých manifestácie sú podmienené súčinnostou rozličných vonkajších faktorov spoločenského aj duchovného charakteru (porov. Botek 2020, 213). Pohladu teologickému je umožnené - čítajúc a interpretujúc vyjadrenia tradície v jej horizontálnej (časovej) dimenzii - dotýkat sa aj dimenzie vertikálnej (nadčasovej, naddejinnej), ktorá je natrvalo ukrytá v tajomstve trojičného bytia, spoločenstva svätých a operatívne sa zjavuje v dejinnom „teraz“ prostredníctvom kultu svätých (porov. KKC 957). Ide tu o poklad zásluh jednotlivých svätých, ktoré - získané „na zemi skrze jediného prostredníka medzi Bohom a lud’mi, Krista Ježiša“ (KKC 956) - predkladajú v postoji orodovania Otcovi, aby tak „upevňovali Cirkev vo svätosti“ a „pomáhali našej slabosti“ (KKC 956). Liturgicko-teologické označenie „slovanskí vierozvestovia“ (Rímsky misál 2001, 712) alebo titul „apoštoli Slovanov“ (Slavorum Apostoli) (Ján Pavol II. 1985), priznaný svätým spolupatrónom Európy Cyrilovi a Metodovi, ${ }^{1}$ dáva termínu „zásluha“ (účinne vyžarujúceho aj do prítomnosti Cirkvi²) konkrétny obsah. Je ním evanjelizačné ohlasovanie - kázanie patriace do samého srdca cyrilo-metodskej tradície (Kocev et al 2017, 92).

Kedže termín tradícia v teologickom význame označuje dve skutočnosti - akt odovzdávania a zároveň odovzdávaný obsah ${ }^{3}$ - (porov. Dei Verbum 1965,č. 8), tak aj cirkevné kázanie rozvíja cyrilo-metodskú tradíciu dvojakým spôsobom: 1. samotnou praxou kázania, t. j. riadnou formou aktívneho odovzdávania Božieho zjavenia, v intenciách kazatel’skej formy svätých slovanských vierozvestov; 2 . kázaním špecificky cyrilo-metodských doktrinálnych obsahov, tvoriacich poklad cirkevne „kanonizovaných“ interpretačných tradícií Božieho zjavenia a zrkadliacich jedinú Tradíciu; sú zachované v ich kazatel’skej spisbe, formálne aj obsahovo nie nepodobnej tvorbe cirkevných otcov ${ }^{4}$ (porov. CEC 1989, č. 45 d) ako jedinečných svedkov Tradície (porov. CEC 1989, č. 18).

1 Za spolupatrónov Európy boli sv. Cyril a Metod vyhlásení 31. decembra 1980 apoštolským listom Jána Pavla II. Egregiaevirtutis (Ján Pavol II. 1980).

2 O mnohorakých zásluhách sv. Cyrila, medzi ktorými vyniká jeho učenie (kázanie) o dokonalej pravde, sa vyjadril pápež Pavol VI.: „Životné dielo svätého Cyrila je bohaté na zásluhy a vyplývajú z neho príklady a poučenia platné i dnes“" (Pavol VI., Homília 1963; Judák - Liba 2012, 84).

3 Fundamentálny teológ Pavol Linet pri objasňovaní pojmu tradícia v jeho dvoch aspektoch uvádza: „Ako vyplýva z etymológie (traditio, parádosis, massoreth), je dôležité chápat tradíciu [...] v jej dynamickej povahe ako proces komunikácie. Výraz tradícia naznačuje odovzdanie niečoho niekomu. Tradícia je [...] proces prenosu celého Zjavenia, celého Kristovho ohlasovania. [...] Nemožno [však] hovorit o tradícii ako procese bez jej obsahu, teda bez toho, čo je tradíciou odovzdávané. Všeobecne je tradícia z hladiska obsahu nazývaná pasívna tradícia (traditio passiva). Vdaka tomuto určeniu je možné jednoznačne odlíšit obsah tradície od formálneho úkonu odovzdávania, aktívnej tradície (traditio activa)“ (Linet 2005, 20-21).

4 Podobnost medzi spisbou cirkevných otcov a slovanských vierozvestov je daná časovou blízkostou ich života s patristickým obdobím..., datovaným na východe do roku 750. Prvky, ktoré robia z písomného dedičstva cirkevných otcov jedinečných svedkov Tradície, sú prítomné aj v diele sv. Cyrila a Metoda: „Diela cirkevných otcov sú striktne pastorálne. Ich spisy sú bud' katechézy, homílie, vyvracania (konfutácie) heréz, alebo odpovede, konzultácie, duchovné povzbudenia či manuály na poučenie veriacich. Na základe toho možno vidiet', ako boli cirkevní otcovia vtiahnutí do pastoračných problémov svojich čias [...], usilujúc sa v prvom rade o uchovanie jednoty Božieho ludu vo viere, božskom kulte, morálke a disciplíne“ (Congregazione per l'educazionecattolica 1989, č. 45d). 
Na uvedené dve dimenzie cyrilo-metodskej kazatel’skej tradície - kázanie ako akt ohlasovania v intenciách cyrilo-metodskej formy kázania a kázanie ako komunikácia obsahov cyrilo-metodskej doktrinálnej tradície - teraz nazrieme oddelene.

\section{Analýza formálnej a obsahovej stránky cyrilo-metodského kázania}

Každý pokus o metodologicko-štrukturálnu analýzu kazatelského diela sv. Cyrila a Metoda naráža na istú fragmentárnost'. O homílii vo vlastnom zmysle slova je pravdepodobne možné hovorit iba v súvislosti s dielami Napomenutie k vladárom (porov. Habovštiaková - Krošláková 1993, 100) a Napomenutie k pokániu (porov. Habovštiaková - Krošláková 1993, 104), ktoré historici pripisujú sv. Metodovi. Napriek skutočnosti, že podstatná čast' kazatel'skej tvorby velkomoravskej misie sa nezachovala, jej formálne aj obsahové prvky sa dajú odvodit zo širšieho celku zachovaného evanjelizačného svedectva(katechéz, napomenutí, apológií, biografií) - homília je totiž jeho špecifickou (liturgickou)realizačnou formou (porov. pápež František 2013, č. 137). Anticipujúc výsledky výskumu, možno skonštatovat', že tažiskovým termínom definujúcim cyrilo-metodské evanjelizačné ohlasovanie po formálnej stránke je zrozumitelnost' - základný predpoklad tzv. inkulturácie evanjelia ${ }^{6}$.

Zrozumitelnost’ cyrilo-metodskej evanjelizačnej misie je primárne spätá s hlavným médiom každej spásnej komunikácie, ktorým je jazyk (jeho alfabetizácia - porov. Ján Pavol II. 1985, č. 21), a potom s rozsiahlou prekladatel'skou prácou do staroslovienčiny ${ }^{7} \mathrm{v}$ zmysle slov sv. Konštantína Cyrila z básnickej skladby Proglas: „Chcem radšej iba pätoro slov povedat, [...] aby aj bratia všetko porozumeli, než nezrozumitelných slov riect’ tisíce“(Konštantín Filozof 2004, 29). V širšom zmysle je zrozumitel’nost’ ohlasovania spätá s „umením prekladu“ do kultúrneho kontextu poslucháča ${ }^{8}$, čiže do „materinskej kultúry“, resp. „materinského nárečia“, ktoré dokáže srdce poslucháča „lepšie pripravené počúvat“ (pápež František 2013, č. 139). Tento typ vnútornej zrozumitelnosti ohlasovaného Slova, o ktorom hovorí Proglas („,hladné ludské duše nakŕmi [...], um aj srdce posilní [...], Boha poznávat pripraví“ - Konštantín Filozof 2004, 17-19), predpokladá - v zmysle slov pápeža Františka o inkulturovanej kázni (porov. pápež František 2013, č. 143) na formálnej úrovni dialogickost', obraznost', naratívnost' i krásu vyžarujúcu z pravdy a na úrovni

5 Na označenie spisu pripisovaného sv. Metodovi (hoci jestvujú viaceré argumenty pre jeho pripísanie sv. Konštantínovi Cyrilovi) sa používa aj označenie „kázňová úvaha“.

6 Podla pápeža Benedikta XVI. predstavujú sv. Cyril a Metod klasický príklad toho, čo sa v súčasnosti označuje slovom „inkulturácia“. Jej predpokladom je zrozumitelnost: „Každý národ musí zakotvit do svojej kultúry zjavené posolstvo a vyjadrovat jeho spásnu pravdu vlastným jazykom. To predpokladá velmi náročnú úlohu prekladu, pretože si to vyžaduje volbu adekvátnych termínov bez toho, aby došlo k znehodnoteniu bohatstva zjaveného Slova" (Benedikt XVI. 2009).

7 Prekladové dielo tvorí podstatnú čast činnosti sv. Cyrila a Metoda. Ide o preklady krstného slubu, vyznania viery nicejsko-carihradskej redakcie, spovednej formuly, modlitby Otčenáš, spovedných modlitieb, evanjelií, Apoštola (novozákonné texty okrem štyroch evanjelií), vybraných častí Starého zákona pre bohoslužobné potreby, žaltára, liturgických kníh, Epifaniovej homílie, právnej literatúry (civilný zákonník, cirkevné ustanovenia), ustanovení svätých otcov (porov. Habovštiaková - Krošláková 1993, 49-76).

8 Túto prácu vystihujú slová Jána Pavla II.: „Aby dobre preložili evanjeliové pravdy do novej reči, museli sa najprv postarat o to, aby dobre poznali vnútorný svet tých, ktorým chceli hlásat Božie slovo dôverne známymi obrazmi a pojmami. [...] Išlo o novú metódu katechézy. [...] Vel'kodušná volba stotožnit sa s ich životom a tradíciou [...] vytvára z Cyrila a Metoda opravdivé vzory pre všetkých misionárov [...], aby zaznievalo jediné Božie slovo a bolo všetkým zrozumitelné podla výrazových prostriedkov rozličných kultúr a civilizácií" (Ján Pavol II. 1985, č. 10-11). Porovnaj tiež Tkáčová et al. 2021, 200-203. 
osobnostnej dispozície kazatela materinskost9 (porov. pápež František 2013, č. 139-143), ako aj d’alšie nevyhnutné duchovné kvality, ukotvené v príklade sv. Cyrila a Metoda, poskytujúce kazatelovi nástroje na pochopenie Božieho slova a jeho evanjelizačne účinnú interpretáciu a komunikáciu: odvahu, modlitbu a pokoru. Ide o trojicu explicitne vyjadrených cyrilo-metodských kazatel'ských vlastností, umožňujúcich účinne ohlasovat’ obsahy kerigmaticko-mystagogického charakteru, ktoré neunikli pozornosti pápeža Františka v homílii zo 14. februára 2017:

„Poslaný, ktorý ohlasuje Božie slovo, má tri vlastnosti: je mužom odvahy, modlitby a je pokorný. Príkladmi sú sv. Cyril a Metod. [...] Títo výborní ohlasovatelia sa naštepili na tradíciu, ktorá čerpá od prvých krestanov. [...] Misionár Božieho slova musí predovšetkým vlastnit úprimnost', silu a odvahu, aby dokázal preniknút do híbky. [...] Ak mu chýba odvaha, môže ohlasovat niečo zaujímavé, morálne či isté filantropické dobro, ale nie je to Božie slovo. Jedine Božie slovo ohlasované s touto úprimnostou a odvahou je schopné formovat' Boží lud. Odvaha musí byt’ sprevádzaná modlitbou. [...] Bez modlitby môžeš urobit peknú konferenciu alebo dat' dobré poučenie. No nie je to Božie slovo. Len zo srdca, ktoré sa modlí, môže vychádzat Božie slovo. Je to modlitba, aby Pán sprevádzal rozsievanie Slova, aby Pán pokropil semeno, aby vyklíčilo Slovo. [...] Ked’ sa kazatel považuje za príliš inteligentného, ked’ sa zodpovedný za Božie slovo chce robit múdrym [...], skončí zle. Je zaiste pravda, že skončíme zle, ak nesieme Božie slovo sebavedome, a nie ako baránok, ktorého chráni sám Pán. Tieto tri črty teda majú charakterizovat toho, kto ohlasuje Božie Slovo. Sú to črty vlastné sv. Cyrilovi a Metodovi [...]: boli to muži odvážni, muži modlitby a pokorní.“

\section{a) Formálna zložka cyrilo-metodského kázania na pozadí súčasného Magistéria}

Ježišova evanjelizačná výzva „chodte do celého sveta a hlásajte evanjelium všetkému stvoreniu“ (Mk 16,15), ktorej z hladiska ontologického i chronologického patrí primát pred každou inou dejinne formulovanou výzvou $\mathrm{k}$ misii, nachádza podla svedectiev Magistéria v evanjelizačnom a kazatel'skom diele sv. Cyrila a Metoda univerzálnu konkretizáciu, inšpiráciu a usmernenie (porov. Benedikt XVI. 2009). Preto nie je metodologicky nesprávne v oživenom záujme teológie i Magistéria o kázanie (ars praedicandi) vidiet zretelnú cyrilo-metodskú stopu a inšpiráciu. Teologicko-pastorálne uchopenie homílie aktuálnym Magistériom - implikujúcim jej formálny aj obsahový aspekt, vnútorne prepojený s osobou kazatela a jeho intelektuálno-duchovno udisponovanostou - sa preto dá kontemplovat’ v jedinečnej cyrilo-metodskej realizácii misijného príkazu Krista, obsiahnutej v hlásaní a katechéze, ktoré vykonávali slovanskí apoštoli. Boli $\mathrm{v}$ „súlade s večnými pravdami a zároveň prispôsobené konkrétnej historickej situácii“ tak, aby si slovanské národy mohli uvedomit” „svoje povolanie mat účast’ na večnom zámere Najsvätejšej Trojice vo večnom pláne spásy sveta“ (Ján Pavol II. 1985, č. 20).Kazatel’ská aktivita vierozvestov nepredstavovala iba partikulárnu dejinnú epizódu, ale stala sa charizmaticky vykonávaným misijným dielom, spočívajúcim vo vytvorení „foriem a štýlov inkarnovania evanjelia do kultúrnej a sociálnej tkaniny, ako aj do mysle európskych národov“. Magistériom Jána Pavla II. je označená za „mílový krok a existenciálny referenčný bod dejinného procesu evanjelizácie Európy, [...] inšpiratívny vzor pre nás, pretože dielo evanjelizácie v špecifickej situácii, v ktorej sa Európa

9 Odkaz na magisteriálny dokument pápeža Františka Evangelii gaudium (2013) má v cyrilo-metodskom kontexte svoju vnútornú logiku. Pápežovo chápanie inkulturovanej kázne, ktorá je podobne ako „rozhovor matky“ nástrojom Slova, a teda prameňom živej vody, výchovy, odvahy, povzbudenia, sily a entuziazmu (č. 139), je možné právom považovat za echo cyrilo-metodského dedičstva vyjadreného v Konštantínovom Proglase. Práve v ňom bolo ohlasovanie prirovnané k materinskému sýteniu duší detí Slovom (Logosom) s cielom posilnit' um aj srdce a dosiahnut poznanie Boha (porov. Konštantín Filozof 2004, 17-19). 
nachádza, je povolané navrhnút novú kreatívnu syntézu medzi evanjeliom a životom“ (Ján Pavol II. 11. 10. 1985; Pontificio consiglio per la promozione della nuova evangelizzazione 2012, č. 214).

Cyrilo-metodská misia $\mathrm{v}$ tomto ohlade predstavuje takú realizačnú formu postpaschálnej misijnej výzvy hlásat evanjelium, akej v duchu dokumentov Cirkvi prináleží prívlastok exemplárna či paradigmatická (Maturkanič et al, 2021, 52-54). Synoptická lektúra II. časti exhortácie Evangelii gaudium (2013) a cyrilo-metodského písomného dedičstva potvrdzuje tézu o trvalej inšpiratívnosti, resp. paradigmatickej exemplárnosti cyrilo-metodského odkazu pre súčasné ohlasovanie evanjelia v kontexte novej evanjelizácie a pastorálnej konverzie (porov. Kongregácia pre klérus 2020), kedže medzi cirkevnými dokumentmi evanjelizačného zamerania as vedectvami o cyrilo-metodskej evanjelizačno-kazatel’skej činnosti možno objavit’ pozoruhodnú materiálnu zhodu. Z toho vyplýva, že to, čo platí o kázaní podla súčasného Magistéria, platí v istom zmysle tiež o kázaní cyrilo-metodskom. A to, čo platí (na základe štúdia prameňov) o cyrilo-metodskom kázaní, možno objavit ako prítomné a rozvinuté v dokumentoch Magistéria. Medzi Magistériom a cyrilo-metodskou tradíciou teda jestvuje istý hermeneutický kruh.

Ak je naším cielom pomenovat hlavné parametre cyrilo-metodského kázania - aby ich bolo možné použit ako kritérium analýzy zvolenej biskupskej homílie a stanovit, do akej miery prispieva k rozvoju cyrilo-metodskej kazatel'skej tradície -, nie je metodologicky nesprávne považovat’ za zásadné práve parametre, ktoré uvádza Magistérium, a to predovšetkým v exhortácii Evangelii gaudium. (Ako už bolo povedané, cyrilo-metodské kázanie je Magistériom kontemplované ako univerzálny vzor ohlasovania; prítomnost' klúčových fragmentov tejto tradície je v dokumente dokázatel'ne prítomné - ukáže to nasledujúca komparácia textov.) Najskôr sa pristavíme pri zhode, ktorá sa týka formálnej zložky homílie - tej, čo má priamy súvis s jej teologickým ukotvením.

\section{Liturgický kontext homílie}

Prvým zásadným vyjadrením dokumentu Evangelii gaudium o homílii je jej umiestnenie do kontextu liturgie (pápež František 2013, č. 137). Je legitímne usudzovat', že to bolo práve silné povedomie o skutočnosti, že celá „liturgia je privilegovaným prostredím, v ktorom Boh k nám hovorí $\mathrm{v}$ prítomnosti nášho života, hovorí dnes k svojmu ludu, ktorý ho počúva a odpovedá mu“ (Benedikt XVI. 2010, č. 52), ktoré sv. Cyrila a Metoda viedli k radikálnemu postoju voči diabolskou závistou inšpirovanej vzbure proti rastu Božieho učenia na Morave (v podobe „trojjazyčníkov“ a „pilátnikov“ - Život Konštantína Cyrila XV.; Vragaš 2013, 66), ako aj radikálnemu postoju vo veci liturgie $\mathrm{v}$ reči ludu. Zápal obsiahnutý v ich otázke „To sa nehanbíte uznávat iba tri jazyky a prikazovat, aby všetky ostatné národy a kmene boli slepé a hluché?" (Život Konštantína Cyrila XVI.; Vragaš 2013, 69) vyjadruje presvedčenie, že liturgia ako celok má byt’ aktom zvestovania smrti a zmŕtvychvstania Krista ako spásy (porov. Sacrosanctum concilium 1963, č. 6), a zároveň presvedčenie, že celok liturgie je autenticky postturíčne a misijné „hovorenie novými jazykmi“ (porov. Mk 16,15). V liturgii sa skutočnost' zjaveného tajomstva ponúka v tele Syna - znamená to, že Božie Slovo sa stáva vnímatelné prostredníctvom „znaku“ ludských slov a gest ${ }^{10}$ (porov. Benedikt XVI. 2010, č. 56).

Stručne povedané, liturgické slávenie je v svojej znakovosti aktom spásneho ohlasovania, a preto si liturgia vyžaduje vonkajšie i vnútorné porozumenie, t. j. plnú vonkajšiu i vnútornú participáciu - participatio actuosa (porov. Ratzinger 1999, 353-354). Toto sú nespochybnitel’ne pravé teologické motívy zápasu svätých bratov o akceptáciu liturgických kníh v jazyku Slovanov.

$\overline{10} \mathrm{~V}$ istom zmysle sa dá o liturgii uvažovat ako o vyššej forme komunikácie spásneho obsahu, v ktorej tajomstvo božského Logosu - ukrytého v obmedzených ludských slovách - je nahliadnutelné a uchopitelné cez jazyk liturgického symbolu a gesta, t. zn. vo väčšej obrazovo-vztahovej bohatosti a rôznosti v zmysle slov: „Kde už teológia nedokáže pomenovat a opísat, tam liturgia začína slávit. Kde už teológia nenachádza presne vymedzujúce slová, tam liturgia objavuje otvorené gestá“ (Juhás 2012, 106). 
Avšak naznačená skutočnost', že medzi liturgicko-sviatostným gestom a slovom je jednota, hoci nie vždy dostatočne uvedomená (porov. Benedikt XVI. 2010, č. 53),zahŕňa i další aspekt - je ním nové a jedinečné hodnotenie ohlasovaného slova zaznievajúceho v kontexte liturgie. Tu dosahuje ohlasované slovo najvyššiu účinnost', pretože „, liturgickom úkone Božie slovo sprevádza vnútorné pôsobenie Ducha Svätého, ktorý ho robí účinným v srdciach veriacich“ (Benedikt XVI. 2010, č. 52). Táto spásna účinnost je daná „sakramentálnostou slova“" ${ }^{\text {“11 }}$ čiže prítomnostou Krista v ohlasovanom slove, analogickou prítomnosti Krista v spôsoboch chleba a vína: „Kristus, skutočne prítomný v spôsoboch chleba a vína, je analogicky prítomný aj v Slove prednášanom v liturgii“" (Benedikt XVI. 2010, č. 56).

Uvedené tvrdenia sa týkajú nielen prednášaného slova Písma, ale aj homílie, o ktorej platí, že „je najvyšším momentom dialógu medzi Bohom a jeho ludom, ktorý predchádza sviatostnému prijímaniu [...], ktoré mení život“ (pápež František 2013, č. 137;138). Vel’mi podobným teologickým presvedčením je preniknutý text Proglasu - aj podla neho cez ohlasované slovo „prichádza Kristus zhromažd’ovat národy“ a nastolit zrozumitelný dialóg lásky, „lebo kto totiž prijme tieto písmená, tomu sám Kristus svoju múdrost vyjavi““ (Konštantín Filozof 2004, 9; 39-40).

Metodologickým dôsledkom, ktorý vyplýva z toho, že homília je s ohladom na svoj liturgický rámec osobitým žánrom, je skutočnost', že „musí byt’ stručná“ (pápež František 2013, č. 138), resp. má byt' „Zaistená vhodná miera rozsahu“ (pápež František 2013, č. 156). Pripisovat’ stručnost” kazatel'ských výstupov vierozvestov len časovému faktoru, ktorý nepochybne vplýval na fragmetarizáciu ich písomného odkazu, by zrejme nebolo historicky opodstatnené. Ucelené slovné útvary podobajúce sa homílii, príhovoru či apológii (najmä v Živote Konštantína Cyrila a Živote Metoda) dosvedčujú sklon solúnskych kazatelov k verbálnej úspornosti v prospech argumentačnej jasnosti a účinnosti, ako aj ich úsilie o to, aby „slovo kazatela nezaberalo príliš vela miesta a Pán mohol zažiarit viac než jeho služobník“ (pápež František 2013, č. 138). Právom je možné o sv. Cyrilovi a Metodovi - o „chudobných tohto sveta a bohatých na vieru“ (porov. Jak 2,5)a „mužoch bohatých na čnosti, usilujúcich sa o dokonalost“" (porov. Sir 44,5) (porov. Ján XXIII., Magnifici eventus; Judák - Liba 2012, 59) - predpokladat, že ich snaha o „správny spôsob hlásania“ bola znakom ich „hlbokého duchovného postoja“, v ktorom všetky svoje schopnosti i kreativitu venovali poslaniu takého ohlasovania, aby druhým „neponúkli veci pochybnej kvality“, čo by sa priečilo „láske k blížnemu“" (porov. pápež František 2013, č. 156).

\section{Materinskost' homílie}

Evanjelizačná dialogickost' homílie - plod neprestajnej činnosti Ducha Svätého v Božom lude -, ktorá zaväzuje kazatela byt’ reprezentantom matky Cirkvi, milujúcej svojich synov, definuje dalšie metodologické požiadavky na homíliu: pozornost’ na signa temporum (znamenia čias a aktuálne potreby ludí danej doby) a sensus fidelium(vieru ludu).

„Cirkev je matkou a [...] dobrá matka vie rozpoznat’ všetko, čo Boh vložil do svojho syna, načúva jeho starostiam a učí sa od neho. [...] Krestanská kázeň v srdci ludovej kultúry nachádza prameň živej vody - jednak pre to, čo treba povedat', ako aj pre objavenie správneho spôsobu, ako to povedat. Ako sa nám všetkým páči, ked’ sa rozpráva v našom materinskom jazyku, tak sa

11 Presvedčenie svätých bratov o tom, čo súčasné Magistérium označuje termínom sakramentálnost', čiže sviatostnost' slova, ktorá sa v plnosti uskutočňuje pneumatickým spôsobom počas slávenia liturgie, možno vnímat aj v systéme hlaholských grafém. Primárnym cielom ich vytvorenia bol preklad Svätého písma a liturgických textov. Ako uvádzajú niektoré hypotézy, tieto grafémy obsahujú prvky krestanskej symboliky, najmä symbolu kríža, čím zjavujú vlastný symbolicko-sakramentálny charakter. Znamená to, že už vo svojej grafickej podobe mali byt’ grafémy nosičmi duchovného zmyslu, resp. médiom ohlasovania (porov. Kralčák 2013, 332-335). 
nám aj vo viere páči, ked’ sa nám kazatel’ prihovára v duchu našej ,materinskej kultúry' a v duchu materinského nárečia (porov. 2Mach 7,21.27), lebo naše srdce je vtedy lepšie pripravené počúvat'. Tento jazyk je naladený tak, že sprostredkúva odvahu, povzbudenie, silu a entuziazmus“ (pápež František 2013, č. 139).

Je zrejmé, že materinské načúvanie (auditus) kultúre i jej jednotlivým predstavitelom dáva homílii existenciálne zacielenie, aktuálnost’ a v spojení s „lahodnostou tónu hlasu, jemnostou štýlu viet a radostou gest“ prináša „ovocie v srdciach jej deti““ (pápež František 2013, č. 140) - je ním otvorenie uší hluchých, počutie slov Písma, zaplesanie nemého jazyka (porov. Iz 35,5;32,4), Božia radosṫ a diablovo zahanbenie (porov. Život Konštantína Cyrila XVI.; Vragaš 2013, 66). Je všeobecne akceptovanou skutočnostou, že evanjelizačný úspech moravskej misie sa kauzálne spájal s pneumatickým načúvaním starostiam i viere zvereného ludu, ktorého imanentnou súčastou bola božská inšpirácia formy aj obsahu evanjelizačného kázania, t. j. objavenie správneho spôsobu, ako a čo povedat: „Nato Filozof odišiel a podla starej obyčaje oddal sa modlitbe. [...] Čoskoro potom sa mu zjavil Boh, ktorý vypočúva modlitby svojich služobníkov a hned zložil písmená a začal písat slová evanjelia“ (Život Konštantína Cyrila XIV.; Vragaš 2013, 64).

Materinskú lásku k zverenému ludu u obidvoch bratov dokazuje tiež zápal, ktorým Konštantín obhajuje právo na vlastný cirkevný jazyk: „Filozof im odpovedal: ,Či neprichádza dážd’ od Boha na všetkých rovnako? A či slnko nesvieti takisto na všetkých? [...] To sa vy nehanbíte uznávat’ iba tri jazyky a prikazovat', aby všetky ostatné národy a kmene boli slepé a hluché? [...] My však poznáme mnohé národy, ktoré majú písmo a oslavujú Boha každý vo svojom jazyku“ (Život Konštantína Cyrila XVI.; Vragaš 2013, 69). A rovnako posledné chvíle bratov sú výrazom ich „duchovného materstva“, ktoré je celkom zamerané na komunikáciu evanjelia v zmysle slov Leva XIII.: „Bez meškania vštepovali ludu krestanské učenie a obracali zrak na nebeské hodnoty. A to robili s takou presvedčivou silou a usilovnostou, že sa Moravania rýchlo a s radostou stali krestanmi. K tomu nemalým dielom prispela znalost' slovanskej reči, ktorej sa Cyril predtým priučil, ako aj preklady Svätého písma, oboch zákonov, ktoré preložil do reči ludu. Preto zásluha tohto muža o Slovanstvo je väčšia, lebo mu lud tejto krajiny vdačí nielen za vieru, ale aj za civilizáciu. Cyril a Metod vynašli písmená, ktorými je reč Slovanov označená a vyjadrená, a preto sa právom pokladajú za tvorcov tohto jazyka“ (Lev XIII., Grande munus; Judák - Liba 2012, 36). Slová sv. Konštantína evokujúce doxologický záver starovekých homílií, ktorými sa završuje „kázeň“ jeho života, sú dojemným vyjadrením lásky matky k detom: „Pane, Bože môj, [...] vypočuj moje modlitby a zachovaj verné ti stádo, nad ktorým si ustanovil mňa, nesúceho a nehodného služobníka. Zachráň ho pred bezbožnou pohanskou zlobou [...], všetkých spoj v jednote ducha a urob znamenitým ludom, rovnako zmýšlajúcim o pravej viere a o správnom vyznaní, a vry do ich sŕdc slovo tvojho prijatia za synov. [...] Tých, čo si mi dal, odovzdávam ti ako tvojich. Spravuj ich svojou mocnou pravicou a skry ich pod ochranu svojich krídel (porov. Ž 61,5), aby všetci chválili a slávili tvoje meno Otca i Syna i Svätého Ducha. Amen“" (Život Konštantína Cyrila XVIII.; Vragaš 2013, 77-78). Chvíle skonu sv. Metoda tiež potvrdzujú jedinečnost vztahu k Moravanom a možno mu opät dat prívlastok materinský (resp. otcovský - porov. Život Metoda XVII.; Vragaš 2013, 110-111).

Ak je homília nástrojoma hlasom matky, nemá íst’ o „kázanie v čisto moralistickom alebo doktrinálnom duchu ani o také kázanie, ktoré sa premieňa skôr na lekciu či exegézu, [ktorá] umenšuje komunikáciu medzi srdcami“. V homílii má byt pravda sprevádzaná krásou a dobrom - nemá íst’ o abstraktné pravdy a studené sylogizmy, pretože „, homílii sa komunikuje aj prostredníctvom krásy obrazov, ktoré Pán používa na podporu konania dobra“ (pápež František 2013, č. 142). Pápež František teda odporúča „hovorenie s využitím obrazov“, ktoré „pomáhajú ocenit” a prijat posolstvo“; cez obrazy „ludia posolstvo počúvajú ako niečo, čo im je známe, blízke, možné, 
spojené s ich vlastným životom“ (pápež František 2013, č. 157). Evanjelizačno-kerygmatické kázanie sv. Cyrila a Metoda malo práve takúto exemplárnu realizačnú formu.

Zakorenenost’ cyrilo-metodskej kázne v existenciálnych a kultúrnych reáliách l’udu a súbežne v Svätom písme - čo jej okrem doktrinálneho obsahu dáva aj biblicko-sapienciálnu názornost', ktorá zosilňuje expozitivíno-apologetickú účinnost kázne bez toho, aby vytvárala v poslucháčovi dojem moralizovania, lekcie exegézy či komunikovania abstraktných právd (porov. pápež František 2013, č. 142) - sa dá potvrdit viacerými textami cyrilo-metodského dedičstva. Osobitne je názorná dišputa o tajomstve Božieho bytia sv. Konštantína s múdrymi a vzdelanými Agarénmi,

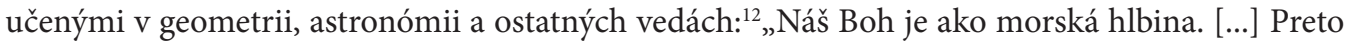
sa mnohí púštajú na tú hlbinu, aby ho hladali. Silní duchom s jeho pomocou ju preplávajú a navracajú sa s bohatstvom múdrosti. No zo slabých a tých, čo sa pokúšajú prejst’ v bútlavých koráboch, jedni sa potápajú a druhí len tažko dýchajú, zmietajúc sa v bezmocnej lenivosti“ (Život Konštantína Cyrila VI.; Vragaš 2013, 30-31).

Rozvíjajúc idey aktuálneho Magistéria o inkulturovanej materinskej kázni mariánskeho typu, možno bez akéhokolvek interpretačného násilia konštatovat', že pamät solúnskych kazatelov je „naplnená Božími zázrakmi“, obsiahnutými v Písme, ich srdcia sú mariánsky „otvorené pre nádej uskutočnenia radostnej skúsenosti lásky, ktorá [im] bola ohlásená“, a preto si jasne uvedomujú, že „každé slovo Svätého písma je predovšetkým darom, nie požiadavkou“ (pápež František 2013, č. 142). Zretelne o tom svedčia slová Proglasu, viacnásobne označujúce Božie slovo za dar Boží: „A preto čujte, čujte toto, Slovieni: dar tento drahý vám Boh z lásky daroval, dar Boží darom spravodlivej čiastky je, dar dušiam vašim, čo sa nikdy neskazí, dušiam tých ludí, ktorí vdačne prijmú ho“ (Konštantín Filozof 2004, 11-13). Vnímanie Božieho slova ako daru vyžaduje od kazatela najprv dôslednú prípravu - „kázeň je natol'ko dôležitá, že je potrebné venovat jej dlhší čas štúdia, modlitby, zamyslenia a pastoračnej kreativity“ (pápež František 2013, č. 145); sv. Cyril a Metod naplnili túto požiadavku exemplárne. Erudovanost’ i duchovnost’ sv. Konštantína potvrdzujú napríklad slová logoteta z čias jeho pobytu v Carihrade: „Tvoja krása a múdrost' ma velmi pobádajú, aby som tá miloval. [...] Tento mladý filozof nemiluje tento život [...], vystrihnime mu tonzúru kňaza a dajme mu službu“ (Život Konštantína Cyrila IV.; Vragaš 2013, 24). Významnú výpovednú hodnotu rovnako majú slová o vnútornej príprave sv. Konštantína na misiu medzi Slovanmi: „Nato Filozof odišiel a podla starej obyčaje oddal sa modlitbe aj s inými pomocníkmi [...] a hned' zložil písmená a začal písat’ slová evanjelia“ (Život Konštantína Cyrila XIV.; Vragaš 2013, 64). Metodovu duchovno-intelektuálnu prípravu misijného ohlasovania zas vyjadrujú slová: „A len čo sa naskytol vhodný čas, zriekol sa kniežatstva a odišiel na Olymp, kde žijú svätí otcovia. Dal sa ostrihat’ a obliekol sa v čierne rúcho. A v pokore sa podroboval, úplne zachovával celú mníšsku regulu a venoval sa knihám“ (Život Metoda III.; Vragaš 2013, 91).

O solúnskych bratoch možno s väčšou istotou než o komkolvek inom tvrdit, že v duchovnej príprave misijnej kázne „venovali pozornost’ biblickému textu, ktorý sa musí stat základom ohlasovania“, že ho „študovali s maximálnou pozornostou a posvätnou bázňou“ i láskou - to všetko v postoji učeníka vyjadreného slovami „hovor, Pane, tvoj sluha počúva“ (1Sam 3,9). Správne pochopili biblický text nielen v pôvodnom význame, ale aj v celkových biblických náukových súvislostiach, „počúvali [ho] s úprimnou otvorenostou“ vo vedomí, že Pán ich chce „použit ako živých, slobodných, kreatívnych ludí, ktorí sa nechajú preniknút jeho Slovom, skôr než ho odovzdajú

12 Iné svedectvo potvrdzujúce biblickú názornost’ evanjelizačného ohlasovania sv. Konštantína predstavuje dišputa s Kozármi na tému trinitárneho bytia a vtelenia, v ktorej sa zrkadlí Filozofovo interpretačné majstrovstvo, citlivo zohladňujúce príklon partnera v diskusii (Kagana) k starozákonnej tradícii; jeho prejavom je argumentácia výlučne starozákonnými biblickými obrazmi v logike predobraz (Starý zákon) - naplnenie (Nový zákon) (porov. Život Konštantína Cyrila IX.; Vragaš 2013, 40-43). 
dalej“. Jeho posolstvom boli vierozvestovia preniknutí na úrovni rozumu i celého bytia, čo bolo darom Ducha Svätého, ktorý inšpiroval Slovo. Tento „aj dnes účinkuje v každom hlásatelovi evanjelia, ak dovolí, aby ho viedol a vnukal mu slová, ktoré by mu nenapadli“ (porov. pápež František 2013, č. 145-151).

Materinsko-mariánska forma rozpamätávania sa vo svetle Písma na Božie zázraky a zároveň v nádeji na ich nové uskutočnenie vytvára v kazatelovi predpoklad pre vytvorenie „syntézy evanjeliového posolstva“" (porov. pápež František 2013, č. 142-143). Syntéza - základ inkulturovanej kázne - je protiváhou komunikovania nesúvislých myšlienok či hodnôt; vytrháva srdce poslucháča z nudy a udržiava ho zapálené a horlivé. Biblicky inšpirovaná syntéza predostiera poslucháčovi celistvost̉ krestanského putovania od krstu až po návrat do otcovského milosrdného objatia v sláve (porov. pápež František 2013, č. 143-144). Podobne cyrilo-metodská kazatel'sko-evanjelizačná tradícia dosvedčuje prítomnost' biblicky inšpirovanej syntézy, ktorá odráža celistvost Zjavenia (porov. pápež František 2013, č. 144), na spôsob východných otcov predstavuje ucelenú soteriologickú doktrínu, vytvárajúcu premostenie medzi protológiou a eschatológiou (porov. Hlad 2013, 536-537). Pri nej sa počúvajúci lud môže neustále cítit „akoby uprostred dvoch objatí“ - krstného objatia a konečného objatia milosrdným Otcom v sláve (porov. pápež František 2013, č. 144). Biblicky ukotvená a teologicky rozvinutá syntéza ako os ohlasovania dáva aj cyrilo-metodskému kázaniu vnútornú logiku a zameranost' na jednotnú tému, „jasný poriadok“, „prepojenie medzi jednotlivými vetami“, jazykovú jednoduchost’ a zrozumitelnost' - vd’aka nim lud dokázal „l’ahko sledovat' kazatel’a a pochopit logiku toho, čo hovorí" (porov. pápež František 2013, č. 158) a mohol dospiet’ k presvedčeniu, „že to je pravá viera“ (Život Konštantína Cyrila XI.; Vragaš 2013, 58).

Ak platia slová, že „niektorí si myslia, že sú dobrými kazatelmi, pretože vedia, ,čo majú povedat, avšak zanedbávajú ,ako', teda konkrétny spôsob podania kázne“ (pápež František 2013, č. 156), potom v prípade evanjelizačného kázania solúnskych bratov možno nepochybne v plnej miere tvrdit, že vedeli, ,ako hovorit aj ,čo hovorit. A práve na obsahovú zložku cyrilo-metodskej kázne sa pozrieme v nasledujúcom výklade.

\section{b) Obsahová zložka cyrilo-metodského kázania na pozadí súčasného Magistéria}

Fragmentárnost' cyrilo-metodského písomného odkazu nespôsobuje tažkosti len úsiliu o sumarizáciu formálnych prvkov ich misijného kázania, ale aj úsiliu o komplexné podchytenie ohlasovaných doktrinálnych obsahov. Neznamená to však úplnú bezmocnost'. Jestvujúce písomné pramene umožňujú lokalizáciu cyrilo-metodského učenia do kerygmaticko-mystagogického kontextu, čo - pri videní ich doktríny ako fragmentu zrkadliaceho celok - znamená dosahovat vysokú mieru poznania teologických tém, ktoré boli pre slovanských vierozvestov tažiskové. Cielom kerygmatického kázania je šírenie viery vo vernosti Pánovmu príkazu: „Naučte ich zachovávat všetko, čo som vám prikázal“ (Mt 28,20); predovšetkým treba ludí naučit nové prikázanie: „Aby ste sa milovali navzájom, ako som ja miloval vás“ (Jn 15,12) (porov. pápež František 2013, č. 161). Druhému aspektu Pánovho misijného príkazu: „Krstite ich v mene Otca i Syna, i Ducha Svätého“ $(\mathrm{Mt} 28,19)$ zodpovedá kázanie mystagogické, ktorého ciel' je rovnako mimo striktne doktrinálnej formácie (porov. pápež František 2013, č. 161): „Ide o to, aby sa človek dal premenit v Kristovi a postupne začal žit’ ,podla Ducha' (Rim 8,5)“ (pápež František 2013, č. 162). Kerygmatické i mystagogické kázania majú svoje privilegované témy. Kedže „kerygma je trojičná“ (pápež František 2013, č. 164), tak aj kerygmatická kázeň musí ohlasovat „Oheň Ducha Svätého [ktorý] sa daruje v podobe jazykov a vd’aka nemu veríme v Krista, ktorý nám svojou smrtou i zmŕtvychvstaním odhaluje a sprostredkúva nekonečné Otcovo milosrdenstvo“ (pápež František 2013, č. 164). Do trinitárneho kontextu načrtnutého kerygmatickým kázaním je následne zasadené centrálne 
posolstvo o spáse v Kristovi: „Ježiš Kristus ta miluje, obetoval svoj život, aby ta zachránil, a teraz žije po tvojom boku každý deň, aby ta osvietil, posilnil a oslobodil“" (pápež František 2013, č. 164). Trinitárno-kristologický obsah kerygmy podmieňuje tiež dalšie kazatel'ské obsahy, medzi ktorými vyniká evanjeliová a harmonicky celistvá téma „zachraňujúcej Božej lásky, ktorá predchádza morálne i náboženské povinnosti“ (pápež František 2013, č. 165); jej slobodné prijatie prináša opravdivú radost', povzbudenie a naplnenie túžby ludského srdca po nekonečne (porov. pápež František 2013, č. 165). Mystagogická forma kázania - nasleduje po stretnutí sa poslucháča so Slovom - má za ciel voviest' veriaceho do konkrétneho ekleziálneho prostredia, ktoré mu umožní intenzívnejší proces duchovného rastu. Táto forma kázania je postavená na liturgických znakoch krestanskej iniciácie (porov. pápež František 2013, č. 166), pričom jej je blízka „cesta krásy“ (via pulchritudinis), podporujúca „zapojenie umenia do evanjelizačnej činnosti v nadväznosti na bohatstvo minulosti, ale aj v šírke jeho rozličných aktuálnych vyjadrení, aby sa viera odovzdávala novým ,jazykom podobenstiev“" (pápež František 2013, č. 167). Dôležitou obsahovou náplňou mystagogickej kázne je morálne posolstvo, „ktoré pozýva rást’ vo vernosti životnému štýlu podla evanjelia“ a zdôrazňuje „ideál života zrelosti, sebarealizácie a plodnosti, vo svetle ktorého možno pochopit odsúdenie každého zla, ktoré by tento ideál mohlo zatieňovat" (pápež František 2013, č. 168).

Misijné kázanie sv. Cyrila a Metoda možno s ohladom na ich cirkevný status učitelov od Boha poslaných v „našom jazyku vysvetlit pravú krestanskú vieru“ (Život Konštantína Cyrila XIV.; Vragaš 2013, 63;porov. Život Metoda VIII.; Vragaš, 98) jasne zaradit’ do kategórie kerygmaticko-mystagogického ohlasovania (kázania). Na prvom mieste ich vysvetlovania pravej viery stojí tajomstvo Najsvätejšej Trojice a spásy v Kristovi. Vierozvestovia celé spásne dielo vnímajú ako dielo Najsvätejšej Trojice: Boh Stvoritel’ cez učitela Krista, resp. Slovo, a Ducha, prítomného v ludských učiteloch, privádza človeka k poznaniu Božieho života, ktorý je ako morská hlbina, k životu, pokoju, podobnosti, obnoveniu, múdrosti (Život Konštantína Cyrila I.-IV.; Vragaš 2013, 17-25). ${ }^{13}$ Spása uskutočnená Kristom, ktorý „dvíha tažké zdola nahor; vierou a Božou milostou učí človeka“ (Život Konštantína Cyrila VI.; Vragaš 2013, 31), a následne sprostredkovaná ludskými učitelmi je v náuke solúnskych kerygmatikov prejavom Božieho milosrdenstva: „A keby sa [človek] aj vel’mi oddával zlu, [Boh] nedopúšta, aby ludský rod upadol [...] a zahynul. Preto po všetky roky a časy neprestáva nám preukazovat' mnoho milostí, ako na počiatku, tak aj teraz, najprv cez patriarchov a otcov a po nich cez apoštolov a mučeníkov, spravodlivých mužov a učitelov, vyvoliac si ich z tohto nepokojného života. [...] To urobil i nášmu rodu, vzbudiac nám tohto učitela, ktorý osvietil náš národ, ktorého mysel' bola omráčená slabostou a ešte viac diablovou lestou, takže nechcel chodit vo svetle Božích prikázani'“ (Život Konštantína Cyrila I.; Vragaš 2013, 17). Na túto trinitárno-soteriologickú

13 S velkou mierou istoty možno tvrdit, že cyrilo-metodská soteriológia je postavená na koncepte gréckej výchovy (paideia), ktorou Boh vychováva človeka (najskôr cez patriarchov a prorokov, potom cez Krista a Ducha Svätého v čase Cirkvi), aby vyviedol na svetlo obraz a podobu, na ktorú bol človek stvorený a ktorá bola zatienená hriechom. Táto výchova, ktorá sa vinie celými ludskými makrodejinami i mikrodejinami, kulminuje v Kristovi - ako prototyp vstupuje do každého obdobia ludského života, a tým obnovuje Boží obraz v človekovi. Človeku tak dáva príklad nasledovania a ten, fascinovaný vnútornou prítažlivostou prototypu, ho napodobňuje, a tým sa zbožstvuje. Boží obraz a podoba, nemoc, záhuba, výchova, učitel', múdrost', obnovenie, dejiny, vtelenie, prototyp, kríž, poznanie, osvietenie, milost', to sú prvky, ktoré umožňujú soteriológiu vel'komoravskej misie lokalizovat’ v súradniciach východného patristického myslenia Irenejovho typu (porov. Hlad 2013, 536-537). 
kerygmatickú os vel'komoravskí mystagógovia pripojili aj rigoróznejšie vyznievajúcu morálnu náuku, ako ju reprezentujú Napomenutie $k$ vladárom ${ }^{14}$ a Napomenutie k pokániu ${ }^{15}$.

Sumarizujúco sa dá povedat, že v celku diela sv. Cyrila a Metodasa objavujú pestré variácie celistvej kerygmatickej zvesti o zachraňujúcej láske Otca, ktorá cez Slovo apeluje na slobodu človeka, aby sa nechal mystagogicky odprevadit do lona Cirkvi. Jej krása sa zjavuje predovšetkým v liturgii - pričom slovanský jazyk je „novým jazykom“ (pápež František 2013, č. 168) - a pozýva k životnému štýlu podla evanjelia, odsudzujúc každé zlo a voliac si vznešené ideály dobra a krásy (Binetti et al. 2021, 28).

Cyrilo-metodská kazatel'ská tradícia v obsahovom aj formálnom aspekte predstavuje i v súčasnosti „dôraznú výzvu“ nasledovat „žiarivé príklady“ v ohlasovaní Božieho slova, „príhodne i nepríhodne [...] so všetkou zhovievavostou a učenostou“ (2Tim 4,2), „verejne i súkromne, v dôverných rozhovoroch od srdca k srdcu“ (Pavol VI., Antiqua enobilitatis; Judák - Liba 2012, 74). Táto tradícia - v duchu slov pápeža Pavla VI. - predstavuje odvážne, každodenné a vynaliezavé ohlasovanie evanjelia zmŕtvychvstania, zvesti radosti a pokoja, prostredníctvom sily slova a príkladu, milosti duchovných darov a s pevným presvedčením, že „naša viera je to vítazstvo, ktorým sme zvítazili, vítazíme i zvítazíme nad svetom“ (Pavol VI., Antiquae nobilitatis; Judák - Liba 2012, 74). Príkladom takéhoto kázania môže byt aj homília z cyrilo-metodskej púte konanej dňa 5 . júla 2020 v Nitre od Mons. Viliama Judáka. Jej analýze sa bude venovat d’alšia čast’ štúdie.

\section{Analýza formálnej a obsahovej stránky homílie Mons. Viliama Judáka z dňa 5. júla 2020 v Nitre}

Homília je jednou z modalít kázania ${ }^{16}$, ktorou biskup ako „autentický učitel““ zaodiaty Kristovou autoritou vykonáva svoj úrad a plní záväzok evanjelizovat častým osobným kázaním toho, čo veriaci „majú verit na Božiu slávu a večnú spásu“, teda „tajomstva spásy v Kristovi - jedinom Spasitelovi a centre života veriacich a celých ludských dejín“ (Kongregácia pre biskupov 2004, č. 120). V homílii, ktorá vyniká medzi ostatnými formami kázania vdaka svojej väzbe na liturgiu („prameň a vrchol života Cirkvi“) a preto, lebo v sebe zahrnuje aj iné formy kázania, sa má biskup usilovat „vyložit katolícku pravdu v jej celistvosti (integrálne), zrozumitelným, familiárnym a lud’om primeraným jazykom, opierajúc sa o texty liturgie dňa“ (Kongregácia pre biskupov 2004, č. 122). O homílii biskupa má zároveň platit, že ako „najvyššia forma ohlasovania Božieho slova“ má byt prednášaná „s autoritou, pretože nepochádza od ludí, ale od samého Boha a so silou, bez toho, aby podlahol z oportunistických dôvodov ludským konvenciám“ (Kongregácia pre biskupov 2004, č. 121). Jej obsahom majú byṫ i „morálne princípy sociálneho poriadku, ohlasujúc tak autentické oslobodenie človeka, ktoré na svet prinieslo vtelenie Slova“ (Kongregácia pre biskupov 2004, č. 120). V prípade, že to vyžadujú práva ludskej osoby alebo spása duší, treba osobitým spôsobom zdôrazňovat hodnotu života, slobody, jednoty a pevnosti rodiny, prokreácie, výchovy detí, spoločného dobra, práce, techniky, materiálnych dobier a ich správneho užívania či bratského

14 Sv. Metod v homílii „žiada kniežatá a vel’možov, aby zachovávali cirkevné predpisy o uzatváraní manželstva medzi krestanmi. Zdôrazňuje najmä manželskú vernost“ (Habovštiaková - Krošláková 1993, 100).

15 Ide o kázňovú úvahu, ktorá napomína k pokornému vyznaniu hriechov, popisujúc hriechy modloslužby, klebetenia, krádeže, vraždy, uspokojovanie telesných potrieb, prísahy, nenávisti ako dôsledky Adamovho hriechu, podmieneného diablom. Rovnako opisuje aj dôsledky hriechu, ako sú starosti, smútok, bolest’ tela, smrtel’nost', strata Božej slávy (porov. Habovštiaková - Krošláková 1993, 104).

16 Direktórium pre pastoračnú službu biskupa okrem homílie spomína pastierske listy a iné formy kázania, ku ktorým patria novinové články, televízne prenosy, stretnutia a konferencie (Kongregácia pre biskupov 2004, č. 122). 
spolužitia všetkých národov (porov. Kongregácia pre biskupov 2004, č. 120). Indikácie Direktória pre pastoračnú službu biskupov (2004) s ohladom na homílie - majúc na pamäti inštrukcie najnovšieho Magistéria ohladom formy a obsahu homílie - podčiarkujú familiárnu zrozumitelnost' (forma) a zameranie sa na obhajobu morálnych princípov sociálneho poriadku, ktoré stoja na Svätom písme a sú zakorenené v náuke Cirkvi (obsah) (porov. Kongregácia pre biskupov 2004, č. 120).

\section{Cyrilo-metodská forma kázne}

Po formálnej stránke možno homíliu Mons. Viliama Judáka z dňa 5. júla 2020 hodnotit ako homíliu reagujúcu na aktuálnu spoločensko-kultúrnu a politickú klímu, definovanú nielen stratou „lásky k jazyku, ku kultúre, k minulosti“, ale najmä absenciou chápania života, jeho kvality, prirodzeného i nadprirodzeného ciela. Jej ambíciou je prostredníctvom istej formy anamnetického rozprávania (národného a duchovného „storytellingu“) podnietit zmenu zmýšlania (metanoia) poslucháčov, ktorá sa (ideálne) prejaví v obnovenom záujme veriacich o časné a večné hodnoty, ako aj v ich aplikovaní v súkromnom a verejnom živote (osobitým spôsobom v priestore politiky), resp. v ich prijímaní a aktívnom odovzdávaní (tradovaní) pre spoločné dobro celého národa/ vlasti.

Homília inšpirovaná liturgickými textami a Božím slovom slávnosti svätých vierozvestov má morálno-parenetický ráz, apeluje na veriaci l’ud aj svetské autority; charakterizuje ju naratívny jazyk, usilujúci sa o zrozumitelnost’ a názornost', čoho prejavom sú parafrázy a citácie viacerých autorít Cirkvi (sv. Augustín, Benedikt XVI., pápež František, Anton Hlinka) či autorít spoločenského života z minulosti alebo súčasnosti (Platón, Aristoteles, Cicero, A. Lauček, J. Baránek). Homília je zretel’ne plodom dvojitého načúvania a kontemplácie - „kontemplácie Slova a tiež kontemplácie ludu“ (pápež František 2013, č. 154). Ide o homíliu predstavujúcu autentický výkon misijnej a evanjelizačnej aktivity biskupa, ktorou sa obracia nielen na veriacich v Krista, ale i na neveriacich a súčasne na všetkých, ktorí intelektuálne alebo prakticky opustili krestanskú vieru (porov. Kongregácia pre biskupov 2004, č. 119). Po formálnej stránke ju teda možno označit za homíliu rozvíjajúcu „cyrilo-metodskú ideu“ kázania (Benedikt XVI., Prejav na generálnej audiencii 17. júna 2009; Judák - Liba 2012, 174).

\section{Cyrilo-metodský obsah kázne}

Po obsahovej stránke platí, že cyrilo-metodské náukové dedičstvo $\mathrm{v}$ homílii vychádza $\mathrm{z}$ dvoch prameňov: biografie svätých bratov a ich písomného diela. Ak platí, že „teológia je podstatne zhrnutá v životopise “17, tak potom „oblúk života solúnskych bratov od zasvätenia sa Božej múdrosti cez misijnú činnosṫ až po istú formu duchovného mučeníctva predstavuje bohatý materiál“ (Hlad 2013, 533) a prameň cyrilo-metodskej náuky, z ktorého homília čerpá inšpiráciu historického a hlavne teologicko-doktrinálneho rázu (Čergetová-Tomanová et al 2021, 544). V tejto súvislosti nie je bezvýznamnou skutočnost', že v prípade Cyrila a Metoda „ide o svätých, čo znamená, že ich biografia odráža ,biografiu' Boha v tomto svete, a preto nám hladajúcim otvárajú ,morskú hlbi-

17 Na biografiu svätých bratov ako špecifické „teologické miesto“ a „životnú syntézu krestanského posolstva“ poukazuje aj Patrik Maturkanič: „Pred nami stoja osobnosti svätých bratov, ktorí autentickostou dokázali už za svojho života (ale aj po ňom) nadchnút nekonečné davy niekol'kých národov. [...] Príchod a pôsobenie Cyrila a Metoda boli pokojné a predovšetkým založené na pravde učiaceho slova, podloženého žitou láskou Ježiša Krista. [...] Títo solúnski velikáni, ktorí položili pevné základy našej kultúry, jasne poukazujú na prototyp najvyššej persony - osoby Božieho Syna, ktorá sa na základe nemenného trojičného princípu lásky stala človekom“ (Maturkanič 2013, 622-623). 
nu' krestanskej múdrosti“ (Hlad 2013, 534) - toto tvorí obsahovú náplň evanjelizačného kázania na spôsob istého teologického miesta.

Za kairologicky významnú považuje biskup Judák tú historicko-biografickú skutočnost', ktorou je vplyv sv. Cyrila a Metoda na proces formovania „velkého národa, ktorý by oslavoval Boha svojím jazykom“ (porov. Život Konštantína Cyrila XIV;; Vragaš 2012, 64). Ako uvádza, „apoštoli Slovanov“, „otcovia vlasti“ či „zakladatelia slovanskej i slovenskej kultúry a štátnosti“ priniesli to podstatné zo symbolických vrchov - z Akropoly záväzok hladat zmysel života a z rímskeho Kapitolu léges čiže zákony a právny poriadok. No predovšetkým „sa stali pre nás evanjeliu svätému Predslovom“ (Konštantín Filozof 2004, 9)a „Slovanov mystagogicky zasvätili do spásnej sily udalosti na Kalvárii, sprítomňovanej v kráse posvätnej liturgie (v rodnom jazyku), čím boli položené základy [...] novej formy verejného života, ktorý stál na ,civilizácii lásky““. A kedže sv. Cyril a Metod významne prispeli $\mathrm{k}$ „vyformovaniu velkého a vyspelého národa, súčasti civilizovaného sveta“, ktorého znakom je základná rovnosť všetkých a ludské práva majúce pôvod v Božom zjavení a Písme (čo „um aj srdce posilní“), „odkial sa dozvedáme, že všetci sme Božie deti stvorené, milované a na večný život predurčené Bohom-Stvoritelom, [...] pôvodcom a garantom našej dôstojnosti, a teda aj legitímneho nároku na život, slobodu a hladanie štastia“, je podla Judáka cyrilo-metodským dedičstvom aj záväzok „uprostred dejinného napätia medzi pozemským a nebeským mestom nerezignovat' na dianie okolo seba, ale sa vzdelávat’ a budovat' nový svet, [...] byt' ako krestan smerujúci do večnosti platným a užitočným občanom aj tohto sveta“.

Centrálnoste cyrilo-metodskej idey patristického pôvodu o povolaní krestanov k zodpovednosti za stvorený svet a spoločnost', implicitne obsiahnutej v ich vonkajšej misijno-formačnej aktivite, potvrdzuje i priamy odkaz na písomné dielo sv. Metoda Napomenutie vladárom: „Preto je každé knieža povinné bez okolkov všetkých, ktorí sú podriadení jeho moci, vyučovat Božiemu zákonu [...] a všetkým každý deň prikazovat', aby nikomu zo slabších nekrivdili ani aby sa nepridŕžali nijakých pohanských obyčaji“ (Habovštiaková - Krošláková 1993, 102).

Homília z nitrianskej cyrilo-metodskej púte teda z komplexu cyrilo-metodskej tradície (biografickej aj písomnej) vyberá, akcentuje a rozvíja ideu aktívneho vnášania krestanských hodnôt do verejného života s cielom prispiet’ k posilneniu krestanskej a národnej identity Slovákov. Je prínosom pre teológiu národa, ktorá tvorí súčast sociálnej náuky Cirkvi a o jej prehĺbenie sa zaslúžil aj sv. Ján Pavol II. (porov. Šuráb 2018, 94-95). Táto idea je následne obohatená o výzvu k zodpovednému odovzdávaniu zdedených fundamentov nastupujúcim pokoleniam, kedže „nenahraditelnou súčastou tradovania týchto hodnôt sme aj my a naša generácia“. Majú byt” „rozumom osvieteným vierou v podmienkach dneška nanovo uchopené, interpretované a zživotnené“ - cez akt tradovania zdedených krestanských morálnych fundamentov totiž „prichádza Kristus zhromaždovat národy, svietit svetlom svetu celému“ (Konštantín Filozof 2004, 9). Ide tu o d’alší explicitný odkaz na písomnú cyrilo-metodskú náukovú tradíciu v kontexte jej aktualizačného rozvinutia, resp. interpretácie racionálnou reflexiou ${ }^{18}$. Analyzovaná homília aj takto zretel’ne dosvedčuje, že dielo sv. Cyrila a Metoda „je stále živé, ba dnes ešte významnejšie a podnetnejšie“ (Judák 2012, 25).

\section{REFERENCES}

Benedikt XVI. 2009. Prejav na generálnej audiencii 17. júna 2009. Dostupné na: http://www.vatican. va/content/benedict-xvi/it/audiences/2009/documents/hf_ben-xvi_aud_20090617.html.

18 V súvislosti s homiletickým rozvinutím cyrilo-metodskej tradície treba mat na zreteli, že „tradícia musí byt živá, aby Cirkev mohla rást'. A prejavom živej tradície je aj jej racionálna reflexia“ (Kondrla 2013, 607). Pre širšie uchopenie homílie v naznačených teologicko-teoretických súvislostiach je vhodné prihliadnut aj na diela slovenských homiletikov (porov. Šuráb 2004; Vrablec - Fabian 2001). 
Homília Mons. Viliama Judáka PRednesená Na PÚti PRi PRíležitosti SLÁVNosti Sv. Cyrila a Metoda DŇA 5. JÚLA 2020 V NiTRE A JEJ PRÍNOS K ROZVOJU CYRILO-METODSKEJ TRADÍCIE

Benedikt XVI. 2010. Verbum Domini. https://www.kbs.sk/obsah/sekcia/h/dokumenty-avyhlasenia/p/dokumenty-papezov/c/postsynodalna-exhortacia-verbum-domini.

Binetti, Maria J. - Králik, Roman - Tkáčová, Hedviga - Roubalova, Marie. 2021. Same and Other: from Plato to Kierkegaard. A reading of a metaphysical thesis in an existencial key. In Journal of Education Culture and Society 12/1, 15-31.

Botek, Andrej. 2020. Cyrilometodská tradícia v ranom stredoveku a problematika architektúry. In Letz, Róbert - Judák, Viliam (eds.). Cyrilometodská tradícia ako spájajúci fenomén. Nitra, 197-214.

Congregazione per i vescovi. 2004. Apostolorum successores - Direttorio per il ministero pastorale dei vescovi. http://www.vatican.va/roman_curia/congregations/cbishops/documents/ rc_con_cbishops_doc_20040222_apostolorum-successores_it.html.

Congregazione per il clero. 2020. La conversione pastorale della comunità parrocchiale al servizio della missione evangelizzatrice della Chiesa. https://press.vatican.va/content/salastampa/it/ bollettino/pubblico/2020/07/20/0391/00886.html.

Congregazione per l'educazione cattolica. 1989. Istruzione sullo studio dei padri della chiesa nella formazione sacerdotale. http://www.vatican.va/roman_curia/congregations/ccatheduc/ documents/rc_con_ccatheduc_doc_19891110_padri_it.html.

Čergetová - Tomanová, Ivana - Maturkanič, Patrik - Hlad, Lubomír - Biryuková, Y. - Martin, Jose, Garcia. 2021. Spirituality and Irrational beliefs of movement activities in Slovaks and Czechs. In Journal of Education Culture and Society 12/2, 539-549.

Dei Verbum. 1965. Dostupné na: https://www.kbs.sk/obsah/sekcia/h/dokumenty-a-vyhlasenia/p/ druhy-vatikansky-koncil/c/dei-verbum.

Habovštiaková, Katarína - Krošláková, Ema. 1993. Z tvorby solúnskych bratov a ich žiakov. Trnava.

Hlad, Lubomír. 2013. Prvky trojičnej teológie v diele „Život Konštantína-Cyrila“. In Lukáčová, Martina et al. Tradícia a prítomnost' misijného diela sv. Cyrila a Metoda. Nitra, 533-541.

Ján Pavol II. 1985. Discorso ai partecipanti al VI Simposio del Consiglio delle Conferenze Episcopali d'Europa 11. ottobre 1985. In Pontificio consiglio per la promozione della nuova evangelizzazione, Enchiridion della nuova evangelizzazione. Cittá del Vaticano, 2012, 173-183.

Ján Pavol II. 1980. Egregiae virtutis. http://www.vatican.va/content/john-paul-ii/it/apost_ letters/1980/documents/hf_jp-ii_apl_31121980_egregiae-virtutis.html.

Ján Pavol II. 1985. Slavorum apostoli. http://www.vatican.va/content/john-paul-ii/sk/encyclicals/ documents/hf_jp-ii_enc_02061985_slavorum-apostoli.html.

Judák, Viliam. 2020. Homília nitrianskeho diecézneho biskupa na slávnost’ sv. Cyrila a Metoda v Nitre 5. júla 2020. http://www.biskupstvo-nitra.sk/homilia-nitrianskeho-dieceznehobiskupa-na-slavnost-sv-cyrila-a-metoda-v-nitre-5-jula-2020/.

Judák, Viliam. 2012. Živé dedičstvo. Bratislava.

Judák, Viliam - Liba, Peter. 2012. Od Petrovho stolca k Velkej Morave. Trnava.

Juhás, Vladimír. 2012. Jazyk ako mocnost' i bezmocnost’ vyjadrenia božského. In Liturgia 12/2, 100-106.

Kocev, Pavle - Kondrla, Peter - Králik, Roman - Roubalová, Marie. 2017. Sv. Kliment Ochridský a jeho pôsobenie v Macedónsku [St. Clement of Ohrid and his activities in Macedonia]. In Konštantínove listy [Constantine's Letters] 10/2, 88-97.

Kondrla, Peter. 2013. Tradícia a jej miesto v náboženskom diskurze. In Lukáčová, Martina et al. Tradícia a prítomnost' misijného diela sv. Cyrila a Metoda. Nitra, 598-607.

Konštantín Filozof. 2004. In Fischerová, Anna et al. Proglas. Prešov, 9-45.

Kralčák, Lubomír. 2013. Pôvod hlaholiky alebo Ako čítat Konštantínov kód. In Lukáčová, Martina et al. Tradícia a prítomnost misijného diela sv. Cyrila a Metoda. Nitra, 307-364.

Linet, Pavol. 2005. Tradícia a zjavenie. Nitra. 
Maturkanič, Patrik. 2013. Velikost života víry svatých slovanských věrozvěstů Cyrila a Metoděje a jejich vliv na evropského člověka žijícího na počátku 21. století. In Lukáčová, Martina et al. Tradícia a prítomnost misijného diela sv. Cyrila a Metoda. Nitra, 621-626.

Maturkanič, Patrik - Čergetová - Tomanová, Ivana - Kondrla, Peter - Kurilenko, Viktoria - Martin, José, Garcia. 2021. Homo culturalis versus Cultura animi. In Journal of Education Culture and Society 12/2, 51-58.

Pápež František. 2013. Evangelii gaudium. https://www.kbs.sk/pdf/FR01/FR01EG2013.pdf

Pápež František. 2017. Homília na liturgickú spomienku sv. Cyrila a Metoda v Dome sv. Marty 14. februára 2017. https://it.zenit.org/articles/santa-marta-cirillo-e-metodioaraldi-del-vangelo-hanno-fortificato-leuropa/.

Ratzinger, Joseph. 1999. Ke struktuře slavení liturgie. In Communio 4, 353-354.

Rímsky misál. 2001. Vatikán.

Sacrosanctum Concilium. 1963. https://www.kbs.sk/obsah/sekcia/h/dokumenty-a-vyhlasenia/p/ druhy-vatikansky-koncil/c/sacrosanctum-concilium.

Sväté písmo. 1996. Sväté písmo. Trnava.

Tkáčová, Hedviga - Pavlíková, Martina - Tvrdoň, Miroslav - Prokopyev, Alexey I. 2021. Existence and Prevention of Social Exclusion of Religious University Students due to Stereotyping. In Bogoslovni Vestnik 81/ 1,199-223.

Vragaš, Štefan (ed.). 2013. Život Konštantína Cyrila, Život Metoda. Bratislava.

doc. ThDr. Lubomír Hlad, PhD.

Constantine the Philosopher University in Nitra

Faculty of Arts

Department of Religious Studies

Tr. A. Hlinku 1

94901 Nitra

Slovakia

lhlad@ukf.sk

ORCID ID: 0000-0003-1690-0057 